\author{
Mariusz Gajewski \\ (D) https://orcid.org/oooo-0ooI-6454-5876 \\ Uniwersytet Papieski Jana Pawła II w Krakowie
}

\title{
Rekonstrukcja tożsamości osób przynależących do kontrowersyjnych grup kultowych i sekt \\ https://doi.org/10.15633/9788374389839.12
}

To nieprawda, że wciągają cię siłą, że do czegoś zmuszają. Oni tylko są obok, gdy ich najbardziej potrzebujesz. Znają lek na smutek i sposób na uczucie bezradności. Otępiają miłością i zrozumieniem. Zaczynasz im ufać, potem kochać... (29-letnia Natalia z Warszawy)

Sekty i nowe ruchy religijne posiadają zróżnicowany charakter. Budzą kontrowersje, są przedmiotem analiz różnych dyscyplin naukowych. Społeczna recepcja ich działalności jest różnorodna. W związku z nasileniem się ich aktywności u progu xxı wieku istnieje społeczna potrzeba pogłębionej analizy ich działania, specyfiki funkcjonowania, form prawnych, jakie przyjmują dla realizacji celów często niejawnych i niejednoznacznych. Dzieci i młodzież to dwie grupy społeczne szczególnie narażone na działanie kontrowersyjnych grup kultowych i sekt. Zarówno pedagodzy, jak i psychologowie, podejmując temat sekt, wskazują na konieczność objęcia młodzieży odpowiednimi programami profilaktycznymi w zakresie przeciwdziałania negatywnemu oddziaływaniu sekt na dzieci i młodzież. Subkulturowy charakter współczesnych sekt wzmacnia ich atrakcyjność, sprawia, że postrzegane są przez młode pokolenie jako atrakcyjne i interesujące. Z drugiej strony stosując wyrafinowane techniki manipulacyjne, współczesne sekty umiejętnie uzależniają od siebie potencjalnych przyszłych adeptów, prowadząc do rekonstrukcji osobistej i społecznej ich tożsamości. Liderzy sekt przekonują, że dzięki nim w społeczności 
sekciarskiej człowiek może „otrzymać” nową tożsamość, stać się „nowym człowiekiem”, „lepszym” bo oświeconym, bardziej świadomym, wybranym itp. Kontrola umysłu i reforma świadomości stanowią przedmiot niniejszych rozważań. Przytoczone historie adeptów sekt ukażą specyfikę manipulacji sekciarskiej, pozwolą lepiej rozumieć, co dzieje się wewnątrz kontrowersyjnych grup określanych mianem sekt.

Psychiczne uzależnienie, ucieczka $z$ domu, rozpad rodziny, konwersja religijna, zerwanie więzi społecznych, egzystencjalne zagubienie, problem z prawem, przemoc, choroby psychiczne, choroby somatyczne, wykształcenie się syndromu sekty, uzależnienie psychiczne od charyzmatycznych liderów grupy - to tylko część z szerokiej palety możliwych konsekwencji pozostawania pod wpływem sekty (Barker 1997; Gajewski 2016; McDowell, Stewart 1994). W niniejszym artykule ukazane zostaną sekciarskie mechanizmy propagandy i manipulacji prowadzące do zniewolenia jednostki, przekształcenia jej świadomości celem ukształtowania tożsamości kultowej.

\section{Charakterystyczne cechy grup kultowych i sekt}

Istnieje wiele definicji sekty (Ashcraft 2005). Niejednoznaczność terminologiczna w zakresie opisu grup kultowych wynika z faktu zróżnicowania form organizacyjnych, jakie wybieraja grupy sektowe, jak i z historii ich pochodzenia i celów, jakie sobie stawiają (Melton 2004; Oliver 2012). Sektami i ich wpływem na jednostkę i społeczeństwo interesują się w sposób szczególny zarówno nauki teologiczne, społeczne, humanistyczne, medyczne i prawne. Brak ścisłej wspólnej terminologii dotyczącej sekt i nowych ruchów religijnych ułatwia grupom tym utrzymywanie aury niejasności pojęciowej, co ostatecznie skutkuje w nauce wielością różnych często sprzecznych - opinii na ich temat, a także trudnościami w kwestii uzgadniania wspólnych stanowisk.

Spotykane na co dzień sekty w zdecydowanej większości hamują możliwości twórczego rozwoju osoby, a pod pozorem troski o dobro duchowe wykorzystują psychicznie, fizycznie i finansowo swoich wyznawców. Sektę możemy więc rozumieć jako pewien rodzaj choroby, która trawi ludzką psychikę, osobowość i jego wiarę, jako ideologię, która degraduje 
człowieka, uprzedmiatawia, niszczy jego wolność, okrada go z siebie samego (Gajewski 2004). Autorzy polskiego Raportu o stanie bezpieczeństwa państwa z 1995 roku (Rozdział viI: Sekty i niektóre związki wyznaniowe $w$ Polsce) zauważają, że sekty wielokrotnie wyłudzają majątki od swoich adeptów, wykorzystują ich seksualnie (w tym dzieci), zmuszają do ciężkich prac fizycznych, znęcają się psychicznie, ograniczają dostęp do opieki medycznej i in.

Analiza zjawiska sekt, jak zauważa Andrzej Zwoliński (2004) najczęściej ogranicza się do opisu kolejnych religijnych zjawisk, przedstawienia genezy ich pochodzenia, ukazania zasadniczych idei, nie precyzując jednak ich istoty. Co więcej, współczesne sekty w sposób dowolny przypisują sobie nazwę "kościołów”, "zborów”, “stowarzyszeń”, “związków”, "kultów”, “ruchów religijnych”, “organizacji”, “szkół”, “centrów”, "religii” itp. Ostatecznie niejasność terminologiczna utrudnia opis sekt, dyskusję nad nimi czy też profilaktykę społeczną (Zwoliński 2004).

Tadeusz Borutka i Jan Wal (2012, s. 65) opisując różne struktury religijne, o sektach piszą w następujący sposób:

Sekta - to mała grupa (wspólnota), która przyjmuje w stosunku do społeczeństwa i różnych tworów religijnych postawę ekskluzywną, to jest zamkniętą i konfliktową, wskutek czego zostaje zepchnięta na margines życia społecznego, a często prześladowana. Wewnątrz sekty panuje klimat charyzmatyczny, co oznacza, że doświadczenie religijne jest dostateczną ochroną jej pierwotnego posłannictwa. Interakcje między członkami przebiegają w klimacie wolności, a nawet, w pewnej mierze, anarchii. Funkcjonowanie sekt zależne jest od kontekstu społeczno-kulturowego. W różnych kontekstach mogą kszta1tować się odmienne postawy: agresywności, tolerancji, asymilacji, pacyfizmu i wielu innych.

Czy wszystkie sekty to grupy niebezpieczne, przed którymi należy chronić dzieci i młodzież? Badacz sekt i nowych ruchów religijnych Aleksander Posacki (1999, s. 2) słusznie zauważa, że światopoglądy propagowane przez sekty są ,niekiedy dziwne i niebezpieczne, niekiedy zaś oryginalne i inspirujące dla poszukiwań intelektualno-duchowych, wchodzących w lukę ludzkich pytań i oczekiwań. Nie wszystkie nowe ruchy religijne są przecież destruktywne i całkiem złe. Sektę można spotkać w łonie każdej 
religii a także w łonie niewiary-ateizmu czy liberalizmu współczesnej kultury”. Wiele współczesnych sekt posiada silny subkulturowy charakter, co wzmacnia ich atrakcyjność, zwłaszcza w kręgach dorastającej młodzieży. Podejmując problem sekt, zwłaszcza z perspektywy nauk społecznych, nie chodzi o nagonkę na poszczególne organizacje uznane za sekty, zwłaszcza że mogą one stopniowo ewoluować, zmieniać swoje oblicze „ulepszać się”, dostosowywać do wymogów prawa i społecznych standardów. Rzetelny opis sekt i ruchów religijnych, a także dobra informacja, są dzisiaj najskuteczniejszą metodą obrony przed ich negatywnym wpływem. Ważne jest dostrzeżenie faktu, że w sektach mamy do czynienia ze zwodzeniem duchowym i manipulacją psychiczną. Badacze zjawiska sekt podkreślają, że pod różnymi pretekstami wąska elita sekt realizuje często swoje ukryte przed adeptami cele. O celach tych wierni nie mają najmniejszego pojęcia. Sekta jest więc miejscem wykorzystania ludzi autentycznie poszukujących lepszego świata, prawdy, wolności i miłości itp. (Gajewski 2004; i in).

\section{Zmiana świadomości i dekonstrukcja tożsamości}

Anthony Giddens określa tożsamość jako projekt refleksyjny. Jego zdaniem człowiek poznaje siebie „w momentach przełomowych, w sytuacjach ekstremalnych, burzących dotychczasowy porządek rzeczy” (Libiszowska-Żółtkowska 2003, s. 110). Spotkanie z sektą jest właśnie tego typu sytuacją, choć nie zawsze uświadomioną. Wejście w orbitę sekty wymusza na potencjalnym adepcie dokonanie zmiany, konieczność porzucenia dotychczasowego modelu funkcjonowania i wejścia w nowe schematy. Zmiana świadomości dokonuje się stopniowo, sekta umiejętnie reformuje umysł i życie swoich adeptów. Złożoność procesu zmiany wymusza wiele czynników natury osobistej, np. osobowość i temperament kandydata do sekty, jak również jego życiowe doświadczenie, więzi rodzinne, koleżeńskie, społeczne oraz specyfika technik werbunkowych pozostających w repertuarze oddziaływań sekty. Dobrze proces ten opisuje Libiszowska-Żółtkowska (2003, s. 110) zauważając, że do „nowej sytuacji trzeba się dostosować, zmienić stare przyzwyczajenia i nawyki, zaakceptować nowe dla siebie zwyczaje”. Wejście w sektę jest czasem przedefiniowywania swojego życia. Tożsamość religijna jednostki zostaje poddana psychologicznym 
mechanizmom „obróbki” umysłu, co prowadzi do rekonstrukcji tożsamości i rewizji przekonań życiowych.

Sekciarska kontrola umysłu i rekonstrukcja tożsamości możliwa jest dzięki zastosowaniu wyrafinowanych technik manipulacyjnych (Gajewski 2015). Warto zauważyć, że manipulować można nie tylko zachowaniem człowieka w danej sytuacji, ale również jego emocjami i sposobem myślenia, seksualnością. Jak podkreśla Joanna Łuczyńska (2004), właśnie z manipulacją mamy do czynienia w przypadku działań sekt. Warto podkreślić, że posługują się nią osoby werbujące nowych adeptów sekt, manipuluje się również tymi, którzy już do sekt przynależą. Warto zaznaczyć, że każdy człowiek jest podatny na manipulację, dlatego sekty w swoje szeregi mogą zwerbować każdego, niezależnie od wieku płci czy poziomu wykształcenia. Jak zauważa autorka:

Łatwiej jest zwabić w szeregi sekty osobę, która nie jest ostrożna, lecz ślepo wierząc we własne siły, bądź kierując się zwykłą ciekawością, da się namówić do uczestnictwa w kursach czy wykładach finansowanych przez nieznane mu organizacje. Podobnie łatwiej jest manipulować człowiekiem, który przeżywa stresy i zawirowania emocjonalne, bądź poszukuje nowych dróg w życiu. W okresach takich przełomów jest bowiem bardziej podatny na argumentację lub propozycje, które są odpowiedzią na jego potrzeby. Jest także wtedy mniej skłonny do wnikliwej i krytycznej refleksji nad argumentami padającymi w rozmowie i wydarzeniami, które go spotykają (Łuczyńska 2004).

\section{Kontrola czasu i ścisła dyscyplina}

Sekty na różne sposoby zabiegają o sprawowanie kontroli nad umysłami swoich adeptów. Istnieje wiele technik kontroli umysłu, wspólnym mianownikiem wielu jest pozbawienie adepta czasu, wypełnienie dnia licznymi obowiązkami, z których są następnie drobiazgowo rozliczani.

Dobrym przykładem tego typu sytuacji jest wspomnienie byłego adepta amerykańskiej korporacji Towarzystwa Strażnica, funkcjonującej w wielu państwach jako Zbór Świadków Jehowy. Ken Guindon, były adept sekty, w następujący sposób opisuje swoje zaangażowanie w działalność Towarzystwa Strażnica w Nowym Yorku: 
W chwili przyjazdu przydzielono nam pokoje i powierzono tymczasową pracę. Przez sześć pierwszych miesięcy w poniedziałkowe wieczory - po ośmiu godzinach i czterdziestu minutach pracy - mamy wykłady z Biblii. Roboczy tydzień trwa od poniedziałku do rano do południa w sobotę. Sobotnie popołudnie jest przeznaczone na chodzenie po domach, a wieczór na inne obowiązki. W niedzielę rano ponownie chodzimy po domach, a po południu uczestniczymy w spotkaniach wspólnoty. «Żelazna zasada» to całodzienne utrzymanie i czternaście dolarów na miesiąc. Dyscyplina jest ścisła, życie nieco wojskowe. Jesteśmy bacznie obserwowani (Guidon 1995, s. 45).

Powyższa historia ukazuje, jak ważnym sposobem kontrolowania umysłu adeptów jest całkowite wypełnienie im czasu przez angażowanie ich w pracę i różne aktywności. W ten sposób przeciętny adept kultu nie ma „fizycznego” czasu na refleksję i krytyczne myślenie.

\section{System awansów, rywalizacja i ścisła kontrola aktywności}

Ścieżka pozornego awansu połączona z ścisłą kontrolą aktywności to inny sposób manipulacji i uzależnienia adepta od sekty. Uzależnienie finansowe stanowi natomiast dodatkowy czynnik wzmacniający motywację do podjęcia aktywności na rzecz sekty. Była adeptka Scjentologii w następujący sposób opisuje swoje uzależnienie od grupy:

W ciągu dnia nie mam chwili wytchnienia, a nad sceptycyzmem przeważa teraz aktywizm, podsycany chęcią wyróżniania się i dojścia do najwyższych poziomów techniki za wszelką cenę. $Z$ drugiej strony klimat, jaki panuje we Flag, jest zaraźliwy, popycha do współzawodnictwa, do rywalizacji. Prowadzę auditing samej siebie i innych całymi dniami. Świat zewnętrzny staje się coraz dalszym tłem dla mojego życia (Gardini 2008, s. 72).

Wciąż nowe wyzwania i możliwość awansowania w hierarchii sekty okazują się doskonałym czynnikiem motywującym do pracy ponad siły. Współzawodnictwo angażuje emocje i utrzymuje stan napięcia. W ten sposób liderzy mogą wymuszać na adeptach decyzje o podejmowaniu kolej- 
nych zadań. Auditing to rodzaj terapii oferowanej przez Scientologów. Sesje są płatne i są doskonałym sposobem na wyciąganie informacji od adeptów sekty. Co więcej, auditing pozwala kontrolować ich własne zachowanie, a sieć wyszkolonych audytorów to inaczej odpowiednio przygotowana grupa osób kontrolujących umysły początkujących adeptów Scientologii.

Do terapii scientologicznej służy elektrometr przypominający wykrywacz kłamstw. To za jego pomocą dokonuje się wzajemna kontrola adeptów Scjentologii. Gardini wspomina:

Moim głównym i nieodłącznym towarzyszem staje się elektrometr ze swymi połyskującymi puszkami, a trzeba powiedzieć, że nadchodzą też premie i uznanie.

W innym miejscu pisze:

W tym czasie jestem prawdziwą kurą znoszącą złote jaja, maszynką do robienia pieniędzy, których nawet cienia my, personel, oczywiście nie widzimy, jest to bowiem służba, misja, i jako taka nie może być odpłatna. Zgodnie z tą filozofią nie istnieją premie pieniężne, lecz jedynie symboliczne wyrazy uznania w postaci paru dolarów (Gardini 2008, s. 72 i 74).

\section{Społeczna separacja i wymóg posłuszeństwa}

Sekta stopniowo zdobywa umysł potencjalnego adepta. Proces zmiany świadomości i nadania nowej, kultycznej tożsamości jest wieloetapowy i rozciągnięty w czasie. Izolacja od najbliższych, kontrolowanie relacji międzygrupowych wzmacniają uzależnienie adepta od sekty i uczą posłuszeństwa. Wiele sekt zabrania swoim adeptom korzystania z Internetu, telefonów i innych mediów. Oglądanie telewizji czy słuchanie radia jest ściśle zabronione. Liczy się tylko to, co dzieje się w obrębie sekty.

Przykład odseparowania od normalnego życia i przymus posłuszeństwa obrazuje historia młodej kobiety, zwerbowanej do niewielkiej polskiej sekty, o czym informowały media, komentując sprawę w następujący sposób: 
Członkowie grupy sami wszystko uprawiali. Zapytałam Mirona wprost, czy są sektą. Uśmiechnął się. «Po prostu jesteśmy przyjaciółmi. Nie mamy nazwy. Wolę, abyśmy nazywali siebie Rodziną, bo dla siebie jesteśmy siostrami i braćmi», powiedział. Postawił jeden warunek: jeśli chcę z nimi zostać, nie mogę kontaktować się ze światem na zewnątrz. Bo jest brudny, a oni chcą od niego uciec [...]. Wstawali codziennie o świcie, po śniadaniu spotykali się na modlitwie [...]. Po modlitwie każdy dostawał przydział obowiązków. Natalia nauczyła się doić krowy, oporządzać świnie, sadzić pomidory i piec chleb [...]. Z czasem zauważyła, że niektórzy współbracia znikają na 2-3 dni, a gdy wracają, są smutni, bladzi, jakby coś złego się wydarzyło. Nikt nie chciał jej powiedzieć, co się dzieje. - Dowiedziałam się po tym, jak nie poszłam na tzw. mszę [...]. Za karę miałam odbyć 3-dniową pokutę. Zamknęli mnie w piwnicy bez światła, bez łóżka. Miałam na podłodze materac, a w kącie przenośną toaletę. Nie mogłam jeść [...] Miron, odwołując się do nauk Jezusa, wymagał od nas posłuszeństwa i podporządkowania się regułom, które miały nam zapewnić zbawienie (Rayzacher, Naj 2011).

\section{Dziwaczne zasady i uzdrowicielskie moce}

Sekty wabią w swoje szeregi ludzi poszukujących zdrowia, uwolnienia od doczesnych trosk i zmartwień związanych z codziennym życiem. Obietnica uwolnienia od różnych bolączek codzienności sprawia, że z ufnością, a często z naiwnością podążają za charyzmatycznymi guru. Podatni na sugestie i manipulację często bezkrytycznie zostawiają dotychczasowe życie, by przyłączyć się do małych „elitarnych” grup sekciarskich fanatyków. Zaślepienie i bezmyślność wynikająca z irracjonalnych oczekiwań otrzymania uzdrowienia ugruntowuje w nich syndrom sekty, czyniąc niezdatnymi do życia poza sektą. Zgoda na życie wedle trudnych i niekiedy dziwacznych zasad może budzić niezrozumienie i niedowierzanie u osób spoza sekty. Przykładem sekty o charakterze terapeutycznym, w której panowało wiele dziwacznych zasad oraz konieczność bezwarunkowego podporządkowania się przywódcy, była polska sekta Niebo (Matla 1996; Pokrzycka 1997; Werbanow 1995).

Do sekty przyjeżdżali ludzie z całej polski. Lider głosił, że jest Bogiem i ma zdolności uzdrawiania ludzi. On sam mówił o sobie „Nie”, a żonę na- 
zwał „Bo” - w ten sposób powstała nazwa sekty „Niebo”. Wśród innych imion członków sekty były: Trójkątyzacja Kota, Papaja Mamaja I Śróbokręt Nie Pomoże, Wulkanizacja Przestrzeni Kosmicznej czy Płonący Olejek. Gdy ogłosił się Bogiem i Sędzią całego świata, zaczął wedle dziwnych rytuałów udzielać ślubów. W sekcie zaczęły rodzić się dzieci, które nie były zgłaszane odpowiednim urzędom, nie były posyłane do szkół. W wyniku biedy i ubóstwa członkowie sekty musieli kraść, bo nie starczało im środków na utrzymanie. $\mathrm{Z}$ jednego $\mathrm{z}$ reportaży na temat sekty dowiadujemy się:

Przychodziła jesień i wszystko ginęło z ogrodów: ziemniaki i tym podobne wylicza jeden z mieszkańców Majdanu. Sebastian wspomina, że członkowie sekty jeździli też do sklepów m.in. w Warszawie i innych miastach. Kradli co popadło. Guru tłumaczył, że po prostu «biorą to, co jest ich». Efektem tych wypraw były pobyty w areszcie. Najgłośniejsza sprawa dotyczyła kradzieży drewna z lasu. Zgłosili ją miejscowi gospodarze. Jak wspomina Sebastian, za kratki trafili wówczas wszyscy mężczyźni ze wspólnoty (Pajuro, Galek 2016).

Były członek sekty wyznaje:

To dla Niebo porzuciłem szkołę teatralną, opuściłem dom rodzinny, poświęciłem własne plany i marzenia. Chciałem się w tej grupie realizować, być apostołem Jezusa Chrystusa, a kończę jak żebrak z reklamówką w ręku, wygnany i poniżony (Pajuro, Galek 2016).

\section{Wartości rodzinne jako wabik i narzędzie indoktrynacji}

Chcąc pozyskać nowych wiernych, sekty odwołują się w swej propagandzie do wartości rodzinnych. Dłuższy pobyt w sekcie ostatecznie prowadzi do rozpadu więzi rodzinnych. Powodów jest wiele. Do wartości rodzinnych przez wiele lat odwoływała się koreańska sekta wielebnego Moona. Sekta ta werbowała swoich wiernych, nie zdradzając potencjalnym adeptom swoich faktycznych celów. Emisariusze grupy, dopytywani o faktyczne cele grupy, sprowadzali wszystkie odpowiedzi do zapewnień, że 
wszystko zostanie ujawnione w swoim czasie. Piotr T. Nowakowski przytacza wypowiedź werbowanego chłopaka do sekty:

Pozwolono mi nawet pytać się podczas wykładów. Później mi jakby zabroniono, powiedziano: odpowiedź usłyszysz na następnym wykładzie, poczekaj jeszcze trochę, i tak kilka razy się powtarzało. Takie odraczanie (Nowakowski 1997, s. 72).

Sekta Moona od lat słynie $\mathrm{z}$ organizowania na stadionach ceremonii ślubnych dla wielu tysięcy par.

W roku 2000 pod przykrywką organizacji znanej jako Federacją Rodzin na rzecz Pokoju Światowego sekta zachęcała młode małżeństwa i młodzież do wyjazdu do Seulu na „tydzień miodowy” i ceremonię zbiorowego ślubu. Imprezie zaślubin towarzyszył Światowy Festiwal Kultury i Sportu „promujący prorodzinne wartości”. Wyjazd, zgodnie z deklaracjami organizatorów, miał mieć charakter prorodzinny, wspierający młode pary, dopiero zaczynające budować przyszłość.

Wartości rodzinne promowane przez sektę Moona mają charakter ściśle religijny (Margul 1998). Warto wiedzieć, że w roku 196o roku poślubił 17-letnią Hak Ja Han, ogłaszając, że są to owe Gody Baranka zapowiedziane w Apokalipsie. Od tego momentu państwo Moon stali się Prawdziwymi Rodzicami Ludzkości. W roku 1997 roku Kościół Zjednoczenia zmienił nazwę i zaprezentował się całemu światu jako Federacja Rodzin na Rzecz Pokoju Światowego. Twórca sekty mami swych członków obietnicą szczególnego błogosławieństwa. Moon jest Mesjaszem, Panem Nieba i Ziemi i posiada on władzę dobierania małżonków. Osoby samotne, mające trudność w znalezieniu sobie życiowego partnera, stanowią doskonały materiał do psychologicznego uzależnienia od sekty.

Sekcie Moona udało się pozyskać w swojej szeregi katolickiego biskupa E. Milingo, któremu zaproponowano związek małżeński. Czas pobytu w sekcie opisuje tak:

Musiałem milczeć. Byłem zmuszony w dalszym ciągu uczestniczyć w tej coraz dziwniejszej indoktrynacji. Czułem, że zaczynam ulegać również psychicznie [...]. Nie wiem, wciąż nie potrafię sobie tego wytłumaczyć. Tu właśnie tkwi problem. Wszedłem do niekończącego się tunelu, a on doprowadził mnie do 
czynów i decyzji, których nie byłem w pełni świadom. Nie wiem jak, nie wiem dlaczego [...]. W którymś momencie tej „katechezy” postawili mi warunek [...]. Miałem połączyć się w małżeństwie z kobietą, która zostanie dla mnie wybrana bezpośrednio przez Moona lub jego współpracownika [...] zgodziłem się (Milingo 2003, s. 43-44).

\section{Manipulacja seksualnością}

Seksualność jest jednym z podstawowych wymiarów bycia człowieka, stanowi integralną część ludzkiej osobowości (Bancroft 2011). Sekty wraz z doktryną religijną i psychologicznym oddziaływaniem na swoich adeptów zawłaszczają również i tę sferę życia człowieka, modyfikując jego tożsamość. Współczesna nauka, opisując seksualność człowieka, wskazuje na następujące jej najważniejsze komponenty: tożsamość płciowa (identyfikacja), tożsamość (orientacja) seksualna, preferencje seksualne, role płciowe, role seksualne (Bancroft 2011). Historia działania różnych sekt wskazuje, że w mniejszym lub większym stopniu nadużywają one ludzkiej seksualności, nierzadko łamiąc prawo.

Przebudowując psychikę, sekty nakładają na adeptów ścisłą dyscyplinę w obszarze życia seksualnego lub przeciwnie - seksualność traktują jako istotne miejsce ekspresji siebie, zezwalając swoim adeptom na otwarty seks, co często prowadziło do licznych nadużyć.

Problem nadużyć seksualnych w sektach nabiera szczególnej wymowy, gdyż dochodzi do nich pod płaszczem idei religijnych i przy odwołaniu się liderów do boskiego autorytetu (Noblitt, Perskin 2000; Hall 2008). Silna indoktrynacja sprzyja uległości adeptów, a podawanie środków odurzających i społeczna izolacja prowadzą do wytworzenia postaw uległości oraz do zaburzenia zdrowej tożsamości. David Berg, amerykański lider sekty Rodzina, do dziś jest ikoną osoby wykorzystującej seksualnie swoich adeptów w imię zasad religijnych (religijna prostytucja). Zarówno on sam, jak i jego sekta przez lata byli oskarżani o liczne nadużycia seksualne (Kent 1994, 2000).

Gromadzenie wiernych rozpoczął od stworzenia grupy Nastolatki dla Chrystusa (Teens for Christ), jednak z biegiem czasu, w wyniku licznych nadużyć, powoływał kolejne grupy, którym zmieniał nazwy. W Pol- 
sce sekta funkcjonowała pod nazwą Wspólnota Niezależnych Zgromadzeń Misyjnych „Rodzina”. Swą popularności zdobyła za sprawą kontrowersyjnej techniki werbowania młodzieży zwanej „flirty fishing” (Kent 20oo). Wśród licznych wypowiedzi o charakterze seksualnym w materiałach propagandowych sekty znajdujemy między innymi: „My mamy seksownego Boga i seksowną religię bardzo seksownego przywódcę z ekstremalnie seksownymi naśladowcami!”, „Jesteśmy bardzo seksowną religią z bardzo seksownym przywódcą i bardzo seksownymi jego naśladowcami i bardzo seksowną doktryną i to wszystko wydobyliśmy z tej książki zwanej Świętą Biblią!”, „Seks i nagość są częścią naszej doktryny, częścią naszej wiary, częścią naszej praktyki i częścią naszej siły oddziaływania!”.

Wykorzystanie seksualne było istotną częścią patologicznego, silnie wypaczonego świata sekty. Jak opowiada jedna z byłych adeptek tego kultu, Christina Babin, już jako 11-latka zmuszana była do sypiania z małżenstwami z sekty. To doprowadziło ją do przeżycia swoistej traumy. W „The Mirror” Grace Macaskill opisała jej historię i to, jak Babin była świadkiem prostytucji i innych nadużyć seksualnych (Bobin, 2018a). Była wtedy 11-letnim dzieckiem, które zamieniono w robota, źródło finansowego dochodu. Opowiada: „Powiedziano nam, że seks to dobra rzecz i że powinniśmy się nim cieszyć. Dlatego też w wieku 11 lat byłam zmuszona do tego, aby wejść do sypialni pewnej pary z sekty. Oni sami chyba nie wiedzieli, co robią. Mieli wyprane mózgi, podejrzewam, że musieli brać narkotyki. Byłam małym dzieckiem, dlatego w pewnym momencie czułam, że ja robię coś źle. Skoro wszyscy mi mówili, że mam czuć się po tym dobrze i czerpać radość, zaczęłam się obwiniać, że po zbliżeniu nie czułam niczego przyjemnego, tylko silny ból. I tak w tym miejscu tkwiłam przez 11 kolejnych lat” (Bobin, 2018b). Seksualny patologiczny obraz ról i zadań płynął od samego przywódcy:

Miałam zaledwie osiem lat, gdy od naszego przywódcy dowiedziałam się, że mężczyzna może robić z kobietą, co tylko chce i kiedy chce. Kobiety i dziewczęta powyżej 10 roku życia zajmowały się wabieniem mężczyzn. Były dziećmi, a musiały uwodzić facetów i chodzić z nimi do łóżka (Bobin, 2018b).

Proces indoktrynacji i uzależnienia od sekty wzmacniała dodatkowo społeczna izolacja jej członków. Christina Babin relacjonuje: 
Kult przyciągnął porzuconych, narkomanów i osoby z problemami psychicznymi. Ludzie cały czas zmieniają swoje imiona, by pozostać incognito. Byliśmy odizolowani od świata, ale mówiliśmy, że to oni żyją w niewłaściwym życiu że nasza droga była właściwa (Bobin, 2018b).

\section{Podsumowanie i wnioski dla profilaktyki}

Autoidentyfikacja człowieka w wymiarze psychologicznym, społecznym i pedagogicznym podatna jest na rozmaitego rodzaju wpływ, tak jednostek, grup, ideologii czy szeroko pojętej polityki, ekonomii, kultury, religii. Rozważając kwestię tożsamości człowieka, wyróżnia się najczęściej dwa jej rodzaje: indywidualną (osobistą) i społeczną. Ta druga zawiera dwa wymiary: subiektywny, określany jako poczucie tożsamości, jak i obiektywny, czyli społeczne zaklasyfikowanie jednostki przez innych (Jarymowicz, Szustrowa 1980). Sekty stanowią realne zagrożenie dla społeczeństwa, a dzieci i młodzież to grupa szczególnego ryzyka. Wszelka profilaktyka społeczna w zakresie przeciwdziałania szkodliwej działalności sekt winna uwzględniać uwarunkowania osobiste (np. osobowość, temperament), kontekst społecznego funkcjonowania (rodzina pochodzenia, więzi społeczne), a także potrzeby o charakterze egzystencjalnym i duchowym. Sekty doskonale wpisują się w potrzeby społeczne, swoją ofertę adresują do konkretnych środowisk i grup społecznych.

Nie bez znaczenia dla ochrony młodzieży są wszelkie przedsięwzięcia wzmacniające poczucie własnej wartości, wzmacniające kompetencje osobiste, a przede wszystkim edukacja i dostarczenie informacji na temat faktycznych skutków przynależności do sekt. Dzieci i młodzież stanowią szczególną grupę ryzyka - ze względu na wiek, gotowość do zaangażowania się w działanie dynamicznych projektów, zadań, grup wolontariackich itp. od zawsze budzą zainteresowanie emisariuszy grup kultowych i sekt. Młodzież poszukująca autorytetów i możliwości zaangażowania niejednokrotnie wikła się w sekciarskie projekty.

Wyjście z sekty jest trudne, nie jest niemożliwe (Clarke 2006; Gajewski 2009). W zależności od stopnia zindoktrynowania zajmuje różnym ludziom od kilku miesięcy do kilku lub kilkunastu lat. Wyrwanie się z sekty wymaga zakwestionowania dotychczasowego życia i otwarcia się na ko- 
lejną reformę myślenia. Pewien były adept sekty czas po wyjściu z sekty opisuje w następujący sposób:

Za kilka dni minie dwa lata odkąd nie jestem Świadkiem Jehowy. W ciągu tych dwóch lat wiele się zmieniło w organizacji, ale też wiele się zmieniło w życiu moim i mojej rodziny. Odejście z organizacji pomogło mi w ułożeniu sobie normalnego życia poza organizacją. W końcu dostrzegam prawdziwy «nieświadkowski» sens życia, mogę cieszyć się po swojemu moim własnym życiem, mogę się cieszyć tym co robię [...] mogę śmiało powiedzieć, że to było genialne posunięcie z mojej strony, podam ku temu kilka argumentów: Relacje z najbliższą rodziną znacznie się poprawiły; Bez wyrzutów sumienia i bez jakichkolwiek obciążeń mogę śmiało studiować swoją ukochaną informatykę; Bez ograniczeń mogę rozwijać swoją pasję związaną z informatyką; Nie muszę w końcu chodzić po domach i «nawracać ich»; Mogę się spotykać z kim chcę; Mogę w końcu słuchać swojego ulubionego heavy metalu [...] moje życie dopiero po wyjściu z organizacji nabiera wielu barw (Rychtar 2019).

Edukacja przez informację i wzmacnianie kompetencji osobistych stanowi doskonałe narzędzie przeciwdziałania zagrożeniom ze strony sekt i kontrowersyjnych nowych ruchów religijnych. Dobrym miejscem dla tego typu oddziaływań obok domu rodzinnego jest niewątpliwie szkoła, a w niej grono pedagogiczne. Współczesna literatura przedmiotu uwikłanie w sektę ujmuje w kategoriach egzystencjalnego zwiedzenia, a nie świadomego wyboru. Wszelkie problemy osobiste i rodzinne związane z przedefiniowanym tożsamości stanowią realny problem społeczny. W tym kontekście należy podkreślić, że również rodzina jako nośnik pozytywnych emocji, wzorców i wartości stanowi istotny punkt odniesienia dla możliwych oddziaływań prewencyjnych.

Nie bez znaczenia dla kształtowania się pozytywnej autoidentyfikacji osobistej i społecznej jest pozostawanie pod wpływem akceptowalnych społecznie norm kulturowych (Radziewicz-Winnicki 2008). Przeciwdziałanie sektom nie może ograniczać się jedynie do reaktywnego przeciwdziałania, zredukowanego do przestrzegania młodzieży przed indoktrynacją i manipulacją. Edukację antysektową należy rozumieć jako część wszelkich oddziaływań wychowawczych, obejmujących szerokie spektrum oddziaływań na dzieci i młodzież (Benner 2008; Kwiatkowski 2002; 
Melosik 2013). Kształtowanie pozytywnych odniesień społecznych, inicjowanie w wartości kulturowe, rozwijanie osobowości to podstawa i punkt wyjścia dla świadomego, zaplanowanego i metodycznego wychowania młodego pokolenia (Śliwerski 2015; Łobocki 2008).

\section{Abstrakt}

Rekonstrukcja tożsamości osób przynależacych do kontrowersyjnych grup kultowych i sekt

Artykuł ukazuje sekciarskie mechanizmy propagandy i manipulacji stosowane przez kontrowersyjne grupy kultowe i sekty. W sposób szczególny analizuje proces zniewolenia psychiki jednostki, przekształcenia ludzkiej świadomości w celu ukształtowania tożsamości kultowej.

Aby wyjaśnić proces rekonstrukcji tożsamości adeptów grup kultowych, w pierwszej części wskazano na najważniejsze cechy grup kultowych i sekt. Następnie omówiono mechanizm dekonstrukcji tożsamości i wieloetapowy proces indoktrynacji sekciarskiej. W dalszej kolejności omówiono kwestie związane z dyscypliną wewnątrzgrupową. Wskazano również na rolę społecznej izolacji adeptów kultów. Ukazano wpływ sekt na życie rodzinne adeptów, propagowane rytuały, strategie werbunkowe i mechanizmy podtrzymujące zaangażowanie.

Artykuł kończą wnioski i postulaty dla praktyki pedagogicznej i psychologicznej. W zakończeniu podkreślono również, że na działanie sekt w sposób szczególny narażeni są ludzie młodzi, zwłaszcza dzieci i młodzież, wszyscy szukający w najbliższym otoczeniu wiarygodnych autorytetów, ludzi i instytucji dających klarowną perspektywę pozytywnego rozwoju osobowego i społecznego.

Słowa kluczowe: sekty, kulty, tożsamość, profilaktyka 


\section{Abstract}

Reconstructing the identity of individuals belonging to controversial cult groups and sects

The paper reveals the sectarian mechanisms of propaganda and manipulation used by controversial cult groups and sects. It specifically analyses the process of enslaving the individual's psyche and transforming human consciousness in order to form a cult identity. In order to explain the process of reconstructing identities of cult group newcomers, the first part points out the most important features of cult groups and sects. Then the mechanism of identity deconstruction and the multi-stage process of sectarian indoctrination arediscussed. This is followed by a discussion of issues related to discipline within a group. The role of social isolation of cult newcomers was also pointed out. The influence of cults on the newcomers' family life, the rituals propagated, recruitment strategies and mechanisms for sustaining commitment were also pointed out. The paper ends with conclusions and suggestions for pedagogical and psychological practice. In the conclusion it is emphasised that it is young people, especially children and adolescents as well as all those looking for credible authorities, people and institutions in their closest surroundings, providing a clear perspective for positive personal and social development that are particularly vulnerable to sects.

Keywords: sects, cults, identity, prevention

\section{Bibliografia}

Abc o sektach, red. M. Gajewski, Wyd. Maternus Media, Tychy 2004. Ashcraft, W.M., A History of the Study of New Religious Movements, „Nova

Religio: The Journal of Alternative and Emergent Religions" 9 (1) (2005), s. 93-105.

Bancroft J., Seksualność człowieka, Elsevier, Wrocław 2011.

Barker E., Nowe Ruchy Religijne, Kraków 1997. 
Benner D., Edukacja jako ksztatcenie i ksztattowanie. Moralność, kultura, demokracja, religia, przeł. D. Stępkowski sDB, Wydawnictwo uksw, Warszawa 2008.

Bobin 2018a, www.mirror.co.uk/news/world-news/cult-leaders-forced-sleep-married (12.01.2021).

Bobin 2018b, www.wprost.pl/zycie/10124441/dzieci-boga-ofiara-sekty-opowiada-o-gwaltach-na-nieletnich-i-znecaniu-mialam-11-lat (12.01.2021).

Borutka T., Wal J., Zarys socjologii religii. Materiaty studyjne, Wyd Czuwajmy, Kraków 2012.

Clarke P. B., New Religions in Global Perspective: A Study of Religious Change in the Modern World, New York: Routledge 2006.

Gardini M. P. Byłam scientologiem, Wydawnictwo Polskie Wydawnictwo Encyklopedyczne, Radom 2008, s. 72, 74.

Gajewski M., Sekty i nowe ruchy religijne, Wyd. Salwator, Kraków 2009.

Gajewski M., Manipulacja umystem i psychiczne zniewolenie w grupach kultowych. Psychologiczna analiza zjawiska, w: Alternatywne światy zagubienia. Religie, ideologie, kulty i New Age, red. I. Kamiński, J. Perszon, J. Kulwicka-Kamińska, t. II, Toruń 2015.

Gajewski M., Fatszywi Nauczyciele. Sekty Dzisiaj, Wyd. Monumen, Kraków 2016.

Hall K., Childhood sexual abuse and adult sexual problems: A new view of sssessment and treatment, „Feminism \& Psychology” 18 (4) (2008), s. 546556.

Jarymowicz M., Szustrowa T., Poczucie własnej tożsamości - źródta i funkcje regulacyjne, w: Osobowość a spoteczne zachowanie się ludzi, red. J. Reykowski, KiW, Warszawa 1980.

Kent S. A., Lustful prophet: A psychosexual historical study of the Children of God's founder, David Berg, „Cultic Studies Journal”, 11 (1994), s. 135-188.

Kent, S. A. , \& Hall, D., Brainwashing and re-indoctrination programs in the Children of God/the Family. „Cultic Studies Journal”, 17 (2000), s. 56-78.

Kwiatkowski S. M., Społeczności lokalne w zarzadzaniu oświata, w: Zadania jednostek samorzadu terytorialnego w zakresie oświaty, red. E. Adamczyk, E. Matczak, Wydawnictwo Instytutu Badań Edukacyjnych, Warszawa2002.

Libiszowska-Żółtkowska M., Konwertyci nowych ruchów religijnych, Lublin 2003. 
Łobocki M., Teoria wychowania w zarysie, Wyd. Pwn, Warszawa 2008. Łuczyńska J., Manipulacja w sektach w: Abc o sektach, red. M. Gajewski, Wyd. Maternus Media, Tychy 2004.

Margul T.,Wspótczesny Mesjasz z Korei, „Euhemer” (1998) nr 2.

Matla P., Inwazja Sekt, „Wprost” (1996) nr 46.

McDowell J., Stewart D., Oszukani, Lublin 1994.

Melosik Z., Kultura popularna i tożsamość mtodzieży. Wniewoliwładzy iwolności, Oficyna Wydawnicza „Impuls”, Kraków 2013.

Milingo E. Ryba wyciągnięta z błota czyli nawrócenie biskupa, Wydawnictwo M, Kraków 2005, s. 43-44.

Melton J. G., Toward a Definition of „New Religion”, „Nova Religio: The Journal of Alternative and Emergent Religions" 8 (1) (2004), s. 73-87.

Noblitt J. R., Perskin P. S., Cult and Ritual Abuse: Its history, anthropology, and recent discovery in contemporary America. Westport, Connecticut: Praeger 2000.

Nowakowski P. T., Sposobypozyskiwania nowych członków przez sekty (praca magisterska), Katowice 1998.

Oliver P., New Religious Movements: A Guide for the Perplexed. London and New York: Continuum 2012.

Pajuro E., Galek E., Sekta w Majdanie Kozłowieckim. Niebo, które umarto śmiercia naturalna, https://plus.kurierlubelski.pl/sekta-w-majdanie-kozlowieckim-niebo-ktore-umarlo-smiercia-naturalna/ar/c111595966 (8.02.2020).

Pokrzycka L., Spótka „Niebo”, „Trybuna” (1997) nr 279.

Posacki A., Wprowadzenie w tematykę Sekt i Kultów, „Drogami sekt i kultów” (1999) $\mathrm{nr} 1$.

Radziewicz Winnicki A, Pedagogika społeczna w obliczu realiów codzienności, WAiP, Warszawa 2008.

Rayzacher B., Byłam w sekcie, „Naj” (2011), https://www.kobieta.pl/artykul/ bylam-w-sekcie (8.02.2020).

rychtar (2019), https://sjwp.pl/bylem-swiadkiem-nasze-historie/po-wyjsciu-z-organizacji-moge-zyc-pelnia-zycia-i-oddychac-pelna-pier$\mathrm{sia/}(8.02 .2020)$.

Śliwerski B., Wspótczesne teorie i nurty wychowania, Oficyna Wydawnicza „Impuls”, Kraków 2015. 
Werbanow R., Krótki katalog polskiego sekciarstwa II, „Czas Krakowski” (1995) $\mathrm{nr} 200$.

Zwoliński A., Anatomia sekty, w: Abc o sektach, red. M. Gajewski, Wyd. Maternus Media, Tychy 2004. 